\title{
La Defensa Rural: \\ los terratenientes y el gobierno conservador de Buenos Aires en el ocaso del régimen oligárquico
}

Roy Hora

Roy Hora es Profesor de la Universidad

Nacional de Quilmes e Investigador del CONICET.

Roque Sáenz Peña 180, Bernal (1876)

Buenos Aires, Argentina.

Teléfono: 43657100 interno 209.

E-mail: rhora@unq.edu.ar

Este trabajo contó con el apoyo de la Fundación Antorchas.

\section{Resumen}

\section{Summary}

Este trabajo analiza la relación entre la elite económica de la provincia de Buenos Aires y el gobierno conservador en los años de ocaso del régimen oligárquico. Para ello estudia la trayectoria de la Defensa Rural, un partido terrateniente creado en 1911 con el fin de enfrentar al gobierno provincial. La Defensa Rural representa un capítulo breve pero significativo de la historia de la clase terrateniente pampeana. El estudio de esta fuerza política contradice la visión dominante sobre el orden oligárquico, que describe a la clase terrateniente como el corazón de la elite gobernante argentina del siglo XIX, y en cambio sugiere una serie de hipótesis que favorecen una mejor comprensión tanto de la posición política de la clase terrateniente como de la políica argentina del cambio de siglo. La trayectoria de la Defensa Rural indica que la relación entre terratenientes y estado en los años de la república oligárquica resulta menos armoniosa de lo que habitualmente se supone, y por ello ofrece elementos valiosos para entender las razones del tan anunciado como poco traumático fin de la república oligárquica.

This article focuses on the relationship between the Buenos Aires landed elite and the Conservative government of the province of Buenos Aires in the last years of the oligarchic regime. For that matter, it analyses the emergence of the Defensa Rural, a landlord-based political party created under the auspices of the Sociedad Rural in order to oppose the provincial authorities. The Defensa Rural is a brief but nonetheless significant chapter in the history of the Argentine landed class. By analysing this organisation, this work seeks to challenge the entrenched assumption of a close unity between large landowners and the state, which has been so central to the historiography on the Argentine landowners for many decades. This article shows that the relationship between landowners and the oligarchic state in turn-of-the-century Argentina was less harmonious than is often argued. This helps to explain the anticlimactic end of the oligarchic republic in Argentina. 